\title{
Arab Teachers' Attitudes towards the Issue of Violence at Schools in Israel
}

\author{
Arap Öğretmenlerin İsrail'deki Okullarda Şiddet Sorununa Karşı \\ Tutumları
}

\author{
Yousef Methkal ABD ALGANI ${ }^{\mathrm{a}}$, Jamal ESHAN ${ }^{\mathrm{b}}$, Nassreen ISHAN-YOUNIS ${ }^{\mathrm{c}}$, Amer HAJ $^{\mathrm{d}}$
}

Öz

Bu araştırma, öğretmenlerin İsrail'deki Arap okullarındaki şiddet sorununa ilişkin tutum ve hisleri ile soruna karşı tepkilerini ve bu tepkileri ifade etme yollarını incelemektedir. okul şiddeti sorunu ve bununla başa cııma yöntemlerine bakıldığında oldukça önemli olan öğretmenlerin șiddet davranıșı kalıplarına yönelik tutum ve hislerine odaklama seçimine dikkat çekmek gerekmektedir. Araştırmacılar, nitel araştırma yaklaşımını benimsemiştir. Görüșme bulguları beş ana kategoriye ayrılmıştır. Bunlar, okula uygun olmayan bir ilişki gösteren öğrenme eksikliği, yabancılașma ve düșük duygu tatmini, eğitim kadrosunun eksik müdahale strateji ve yöntemleri ile şiddete neden olan kişisel ve ailesel etkenlerdir. İsrail'deki Arap bölgesinde artan şiddet oranları bu araştırmayı önemli hale getirmektedir.

Anahtar Kelimeler: Öğretmen Tutumları, Şiddet, Arap Bölgesi

\section{Abstract}

The present study examines the teachers' attitudes and feelings concerning the issue of violence in Arab schools in Israel, the teachers' reactions towards that issue and ways of expressing them. The choice to focus on teachers' attitudes and feelings towards violent behavior patterns, which is of paramount importance, must be taken into account when accessing the issue of school violence and ways of dealing with that. The researchers adopted the qualitative approach. The findings of the interviews are divided into five main categories: lack of learning, alienation and low emotional appreciation, lack of strategies and methods of intervention of the educational staff, which receive inappropriate relating at school, as well as personal and family factors, which lead toward violence. The importance of the study stems from the increase in the violence rate in the Arab sector in Israel.

Keywords: Teachers' Attitudes, Violence, Arab Sector

\section{Makale Hakkında}

Tür: Araştırma

Geliş Tarihi: 28 Ocak 2020

Kabul Tarihi: 16 Haziran 2020

Yayın Tarihi: 4 Temmuz 2020

DOI:

Sorumlu Yazar

Yousef Methkal ABD ALGANI

Sakhnin College

Sakhnin/Israil

E-posta: yosefabdalgani@gmail.com

\section{About the Article}

Type: Research

Received: 28 January 2020 Accepted: 16 June 2020 Published: 4 July 2020 DOI:

Corresponding Author: Yousef Methkal ABD ALGANI Sakhnin College Sakhnin/Israel

E-mail: yosefabdalgani@gmail.comr

\section{Önerilen APA Atıf Biçimi / Suggested APA Citation}

Abd Algani, Y. M., Eshan, J., Ishan-Younis, N., \& Haj, A. (2020). Arab teachers' attitudes towards the issue of violence at schools in Israel. Academy Journal of Educational Sciences, 4(1), 31-43. http://dx.doi.org/10.31805/acjes.681402

aYousef ABD ALGANI-ORCID: https://orcid.org/0000-0003-2801-5880

Sakhnin College, Faculty of Education, Department of Teaching Mathematics, Sakhnin, Israel. E-mail: yosefabdalgani@gmail.com

BJamal ESHAN-ORCID: https://orcid.org/0000-0002-1175-6926

Sakhnin College, Faculty of Education, Sakhnin, Israel. E-mail: gamale@walla.com

c Nassreen ISHAN-YOUNIS-ORCID: https://orcid.org/0000-0002-3620-0640

Independent Researcher, Israel. E-mail: sonaayones@gmail.com

${ }^{d}$ Amer HAJ-ORCID: https://orcid.org/0000-0002-0899-1000

Elbashaaer High School, Israel. E-mail: amer100haj@gmail.com 


\section{Introduction}

Álvarez-Garcia and his colleagues define the concept of violence, in so far, as a behavior intended to cause personal injury or harm (Álvarez-Garcia, Rodríguez, González-Castro, Núñez, \& Álvarez, 2010). The research literature on school violence most often emphasizes the importance of the school climate to reduce the number of victims and to create a safe school environment (Cornell, Shukla, \& Konold, 2015). School violence has significant implications for the school, the teaching staff, and students' achievement. School violence has a number of forms. It can be expressed in violent conducts, performed by the administration panel, the teachers' staff, the parents, the students and any other school-involved persons, towards any individual who is considered part of the school. The purpose of the present work is not reviewing all the forms of school violence, but rather focusing on violence conducted by students towards their peers (Berkowitz Glickman, Benbenishty, Ben-Artzi, Raz, Lipshtadt, \& Astor 2015; Lacey \& Cornell, 2013).

The meaning of students' violence is mainly expressed by teachers who feel threatened to get involved effectively with violent students. The teachers' staff may spend more time in preventing students' fights and less time on conveying educational contents. Such mechanisms act as an "emerging" phenomenon at the school level, rather than a student's.

\section{Violence at School}

There is no one definition of school violence. According to Danner and Carmody, school violence refers to violence that occurs at school, starting from kindergarten till high school (Barrett, Lynch, \& Stretesky, 2016; Danner \& Carmody, 2001). Elliott and others have provided a different definition of school violence, which is accepted by quite a few scholars. They say that violence relates to using threat or any form of physical force with the intent to cause bodily damage, injury, or intimidation of another person (Elliott, Hamburg \& Williams, 1998; Barrett, Lynch \& Stretesky, 2016). According to this definition, the focus is on the interpersonal acts of violence, such as hurting or pushing another person with the intent to hurt or intimidate him/her.

According to Addington, the definition of school violence has changed over time (Addington, 2009). For example, the earliest definition of school violence has focused mainly on assault and robbery, however, the contemporary definitions of school violence encompass a range of behaviors which differ in their severity, starting from verbal threats to deadly assaults. Hence, the need to further explore the role of power dynamics in school violence, as well as the need to examine school violence beyond the interpersonal acts, has emerged.

\section{The Development of Violence within The School}

School is not only required to achieve the highest academic performance and achievement, but also demanded to ensure a safe school environment. However, school conflicts and fights are noticeably increasing at younger ages (Moral, Suárez, Villareal, \& Musitu, 2014; Pérez-Carbonell, Ramos-Santana, \& Serrano, 2016). Adolescence is characterized by intense changes and stages of transition in the adolescents' domains of development: physical, psychological, and social (Moral, Suárez, \& Musitu, 2012).
The family, the school, and the community collectively foster the adolescence psychosocial adaptation (Herrera, Romera, Ortega, \& Gómez, 2016). Adolescence is a critical transition stage in the human development which is characterized by a multiple of spasmodic conditions and variables. The literature review emphasizes the huge impact of the phenomenon of school violence, at this stage of education; school violence damages the learning process, the evolutionary development and the safe co-existence at school. In addition, the phenomenon of school violence has negative consequences for adolescents' well-being, psychological health and social relationships (Estevez \& Jiménez, 2015).

The research literature offers two major approaches to explain the school violence conducted by adolescents: the psycho-dynamic approach, which views violence and behavioral problems as innate instincts in the human personality; and the social learning approach which determines that violence is influenced by the environment.

Freud, who represents the psycho-dynamic approach, assumes that there are two main innate instincts that guide the individual's behavior (Noymeir, 1992):

a. The Eros: Life instincts (the impulse of sex and life); the instincts that push man into creation and construction and maintain his survival.

b. Thanatos: Death instincts (the impulse of aggression and death); instincts that push a person towards self-destruction, or harming others and damaging property, that is, violence and aggression.

In accordance with this approach, aggression is often unconscious and it drives the person into acts of destruction and hatred for himself and others. The accumulation of this very unconscious aggression requires ways to release the stress. Guiding the aggressive forces into channels of donation, both for individual and the community, stop the aggression and prevents the system from collapsing.

At the same time, according to the social learning approach, Bandura (1983) argues that the external environment has a strong influence on one's behavior. Bandura argues that violence, or rather non-violence, is a behavior people learn through punishment and rewarding. If a certain behavior is punished, that behavior may not be repeated. Also, patterns of behaviors are acquired by watching an influential model like parents, teachers, students or movie stars. Aggressive behavior which results in positive results, is specially emulated. The continuity of the violence depends on the reinforcements the environment provides: violence stops as long as there are no reinforcements. Bandura argues that the social learning mechanism is governed by positive reinforcements, and the impetus of violence is the negative reinforcement or aggressive conditions provided to the individual (Bandura, 1983; Amit, 2012).

The social learning approach emphasizes the importance of cognitive processes involved within the individual's data processing: when punishing the individual who commits violence, in fact, others will refrain from acting violently. According to Bandura, the main learning mechanism is imitation. Each person has a tendency to imitate others. When the violence model is rewarded, the individual's tendency to emulate this violence increases, whereas when this model 
is punished, the individual's degree of aggression deceases considerably. Hence, rewarding legitimizes aggression; when violence is not justified and legitimized then aggression should not occur (Margaleit, 1998).

Goldstein summarized his interpretations of the learning theory, in relation to violence, in three points (Goldstein, 1996):

1. Acquisition: The process of acquiring violent behavior is influenced by the individual's biological infrastructure: hormones, the central nervous system, and other physical elements. Each person has a neuropsychologist ability to acquire violent behavior and inculcate it in his/her list of behaviors.

2. A leading stimulus: When a particular person has a list of violent behaviors in his/her background, there is a number of factors that cause those violent behaviors such as frustration, unfair life difficulties and physical or verbal threats. Another factor that drives a person towards violence is watching violent and emotional behaviors.

3. Conserving Violence: Violence will continue to exist if it receives justified support or recognition. The violent person may increase his/her violence by justifying his actions or by transferring the responsibility for his/her violence to other people. It is also possible for the violent person to receive additional reinforcement when the attacked person suffers greatly out of violence.

Alongside these two theories, the research literature has highlighted three main factors that lead the individual towards aggression (Noymeir, 1992):

1. Frustration: Noymeir (1992) was the first to analyze aggression in motivational terms. In his opinion, the main variable that leads to violent behavior is frustration. The individual's frustration is considered to be an unpleasant emotional situation caused by not achieving the individual's desires. Alongside this, there exist the external factors that block the person's attempts to achieve his/goals, and so frustration awakens the aggression implanted in him. Therefore, whenever a person feels frustrated, aggression is likely to be expected. According to the frustration model, the individual's emotional arousal can lead him/her into aggression. In this way, the student has feelings of insecurity, worry or lack of learning; the more the student feels that $\mathrm{s} / \mathrm{h}$ e fails to study, the more $\mathrm{s} /$ he is likely to adopt violet behaviors (Hess, Horowitz \& Reiter, 2009).

2. Loneliness: Many scholars have described loneliness as an unpleasant experience, accompanied by negative feelings. This experience stems from the lack of interpersonal relationships that leads to dissatisfaction of the social relationships. Loneliness is seen as a general characteristic of children/youth who have intellectual disabilities. The feeling of loneliness makes it difficult for the individual to develop social relationships and reinforces his interpersonal difficulties. Therefore, one of the ways lonely individuals use to deal with pain and frustration caused by social alienation is using violence. In this way, a sense of alienation from the school appears - the more the student feels disconnected from school, the more he is likely to act violently (Abu Asaba, Karakra-Ibrahim and Abu Ketsh, 2018).

3. Positive Feedback: In line with the operative conditioning theory, violent behavior is acquired, like any other learning, by reinforcing this behavior. Bandura emphasizes the concept of reinforcement, arguing that people will be more violent when their violent behavior is rewarded by positive reinforcements. Unlike the operative conditioning theory, Bandura argues, one can draw such a conclusion without being violent (Horovetz \& Frenkel, 1990). In this way, a violent school environment, lack of strategies and methods of intervention of the school staff, and the sorts of attitudes towards a violent child, teach the student to respond violently as a normative expression in the environment in which s/he lives (Hess, Horowitz \& Reiter, 2009).

Therefore, in line with the learning theory approach, the more a student feels that violence is an integral part of his/ her school, the more s/he will tend to resort to violent ways. A violent school environment is poisonous and it exposes the students to values that do not negate the phenomenon of violence, causing the students to adapt to such environment, and see violent behaviors as acceptable (Hess, Horowitz and Reiter, 2009).

In addition, the severity of violence varies according to three types of characteristics (National Authority for Measurement and Evaluation in Education in Israel (RAMA, 2016), the characteristics of the individual, school characteristics and external-school characteristics.

a. The characteristics of the individual: The most prominent individual characteristics that influence the phenomenon of school violence are the age and gender of the students. The findings of RAMA (2018), noted later in this work, indicate a decrease in the rates of the reported victims of all forms of violence along the increase in age, except for the sexual violence in which the rates of victims increase along the grow in age. In addition, Reuveni (2011) points out significant gender differences when it comes to violence victimization. Boys get hurt more than girls from verbal, physical and sexual violence. She explains this based on the fact that boys, more than girls, tend to report being involved in violent acts, which raises the likelihood that they will also become victims.

b. School characteristics: According to RAMA (2018), the characteristics that affect the phenomena of school violence and the level of violence are: bringing cold weapons to school; avoiding school attendance for fear of injury; school transportation violence (the frequency of cases the student has been a victim of verbal or physical violence in school transportation); violent gangs and bullying at school: (frequency of events of this type at school); Use of psychoactive substances (frequency of use of various psychoactive substances, ranging from alcoholic to drug); students' sense of security; and the school's efforts to prevent 
violence. A positive climate in the school lowers the levels of school violence.

c. External-school characteristics: the community in which the school is located and the ethnic as well as the economic background of the students, have an impact on school violence. A community characterized by poverty, high crime rates, discrimination, a paucity of educational opportunities and employment is an environment that increases the likelihood of violence, even within the school. Another external-school characteristic that predicts the level of school violence is the ethnicity and culture of the students' families. One more external-school feature is the parenting style in the child's family which also affects the child's chances of behaving violently, i.e. parenting styles that are not characterized by warmth and direct involvement in the child's daily life, and also parenting styles that do not set clear rules of acceptable and unacceptable behavior, or permits aggressive behavior. Parents who are themselves models of violence increase the likelihood that the child will internalize this model and become violent himself (RAMA, 2016).

\section{Different Forms of School Violence}

Violence harms the victim physically, verbally or emotionally. According to Reuveni (2011), verbal violence is directed at the victim both directly and actively, which harms his emotions, such as curses, humiliations and insults. In contrast, emotional violence is directed at the victim indirectly through social rejection, preventing him/her from participating in social activities, imposing a boycott on him/her to be with a group, spreading humiliating rumors about him through social networks, and so on.

Such violence is expressed in various forms at school (Benvenishti, Khuri-Ksabari \& Astor, 2005: RAMA, 2011):

- Verbal violence (Defensor del Pueblo-UNICEF, 2007): This violence is intended to hurt both verbally and emotionally using abuses (curses), insults and humiliations (including social boycott).

- Moderate violence: This violence is divided into: (a) violence of direct and indirect threats. This violence is intended to hurt emotionally by intimidation and extortion and (b) physical violence (Álvarez, Álvarez-Garcia, González-Castro, Núñez, \& González-Pienda, 2006), which is intended to physically hurt by pushing, striking, slapping and so on.

- Severe violence: This violence is divided into: (a) particularly severe physical violence such as very strong beatings or those requiring medical treatment; (b) violence of using weapons of all kinds. This violence is intended to hurt emotionally and physically using knives, sticks and stones for threat or injury and (c) vandalism, which is intended to hurt emotionally by extorting money, food or valuables.

- Social Violence (Pachter, Bernstein, Szalacha, \& Coll, 2010): this violence is intended to emotionally hurt by imposing a boycott, disconnecting and spreading offensive rumors.
- Violence using digital communication information (ICT) (Álvarez-García, Barreiro-Collazo, Núñez \& Dobarro, 2016): this violence is intended to hurt emotionally by distributing abusive images, sending insulting or abusive messages, or sending threats online or on the cell phone, or by using social networks like Facebook to hurt others.

- Sexual Violence: this is violence of harassment and sexual abuse. This violence is intended to verbally, emotionally and physically hurt by verbal harassment, spreading insulting rumors, glimpses, unwanted physical contact in intimate places or exerting pressure to expose intimate organs.

A number of studies examining the relationship between adolescent gender and school violence indicated higher prevalence in boys than girls in situations with a strong social impact (violent and physical aggression), whereas the prevalence of low-intensity violence (rumors or insults) was higher in girls than in boys. (Calvete, Orue, Estévez, Villardón \& Padilla, 2010)

In comparison, previous studies found no significant gender differences regarding indirect violence, but a higher prevalence of direct violence was observed in boys (Peets \& Kikas, 2006).

As for the link between adolescent gender, school violence, and the use of digital communication information, several studies have emphasized that girls more than boys fall victim to violence through this technology, while boys are more aggressive in it (Félix-Mateo, Soriano-Ferrer, Godoy-Mesas, \& Sancho- Vicente, 2010; Peterson \& Skiba ,2001).

\section{The Extent of Violence in Schools in Israel}

In 2005, the Ministry of Education established the National Authority for Measurement and Evaluation in Education (RAMA) as a unit of reference for conducting research and evaluation in the educational system in Israel. Close to its establishment, during the school year-2006/7, the Director-General of Education asked RAMA to lead a process of developing a unified and conventional tool to monitor the level of violence in schools (Ram, 2018).

In light of this request, RMA convened a committee that included representatives from the Ministry of Education who deal with the phenomenon of violence (psychological counseling service \& social and youth director) and experts from the academy. Based on the committee's work, a number of detailed questionnaires were developed for both the students and the teachers to examine the variety of manifestations of violence at schools. The questionnaires were first carried out among a representative national sample of 4 th till 11th students during the school year-2008. The process was repeated in the 2011, 2013, 2015 and 2017; and this should continue to be carried out every other school-year. This process of monitoring school violence is of great importance, as it enables systematic and comparable periodic monitoring of the level of violence in schools in Israel (RMA, 2018).

According to RAMA's report (2018), metrics were calculated on the following topics: verbal violence, moderate violence, severe violence, social violence, violence using digital media 
and sexual violence, among 24,145 students: 8,724 from elementary schools, 8,935 from junior-high schools and 6,486 from high schools. The division based on language and supervision sector is the following: 5.568 students from Hebrew-speaking official schools, 4,830 from Hebrew-speaking religious schools and 13,747 from Arabic-speaking schools (This category includes schools belonging to the Arab, Druze \& Bedouin sectors)

In addition to these metrics, by which students were asked to report on events that happened to them or behaviors they performed during the month preceding the questionnaires, they were asked to respond to additional statements on the following topics (RAMA, 2018):

a. Violence in school transportation: the frequency of cases where the student was a victim of verbal or physical violence in the school vehicle.

b. Violent gangs and bullying at school: the frequency of events of this type at school.

c. Use of psychoactive substances: frequency of using various psychoactive substances, ranging from alcoholic beverages to drugs.

d. Students' sense of security: the index is calculated by the average of the students' percentage who agree with the statements.

e. School efforts to prevent violence: the index is calculated by the average of the proportion of students who agree with the statements.

RAMA's report (2018) indicates the following:

(1) Verbal violence: Between the years 2008 and 2017, the rates of the reported victims of verbal violence in each age group declined. It has also been found that the rates of students reporting victims of verbal violence are higher in younger ages (i.e. the lower the age the higher the verbal violence); they are $42 \%$ in grades 4 th-6th, $34 \%$ in grades 7 th-9th and $22 \%$ in grades 10th-11th. In addition, the rate of students reporting victims of verbal violence in Hebrew-speaking schools (36\%) is higher than in Arabic-speaking schools (31\%), especially in 4 th to 6 th grades.

(2) Moderate violence: From 2008 to 2017, the rates of students reporting victims of moderate violence, decreased at each age group. It is also found that the rates of students reporting victims of moderate violence are higher in younger ages (i.e. the lower the age the higher the moderate violence); they are 25\% among 4th-6th graders, $14 \%$ among 7 th-9th grades, and $9 \%$ for grades 10th-11th. In addition, the proportion of students reporting victims of moderate violence in Hebrew-speaking schools (15\%) is lower than in Arabic-speaking schools (21\%). The gap between the sectors in grades 10th-11th (8\%) is higher than the gap in grades 4 th-6th and grades 7 th-9th (5\%).

(3) Serious violence: Between 2008 and 2017, there was a decrease in the rate of students reporting victims of serious violence in grades 4th-6th and 7th- 9th. Also, during this period, there has been a decline in the rate of students who reporting bringing cold weapons to school. Moreover, it was also found that the proportion of students reporting victims of severe violence was higher among 4th-6th graders (13\%) compared to 7th-9th graders and 10th-11th graders (7\%). In addition, the proportion of students reporting victims of severe violence in Arabic-speaking schools $(15 \%)$ is significantly higher than the proportion of students in Hebrew-speaking schools (7\%). The gaps between the sectors are greater in grades 4th-6th and grades 10th-11th (about $8 \%$ ) compared to gaps in grades 7 th-9th $(6 \%)$.

At the same time, the rate of students who report bringing cold weapons to school is low; it is about (1\%) in grades 4 th-6th, $(2 \%)$ in grades 7 th-9th and $(3 \%)$ in 10th-11th. In addition, the rate of students who report bringing cold weapons to school in Arabic-speaking schools (4\%) is higher than Hebrew-speaking schools (1\%). The gap between sectors is greater in grades 10th-11th (5\%) than in grades 7th-9th and grades 4th6th (approximately $1 \%$ )

(4) Social violence: from 2008 to 2017, there was a consistent trend of a decline in the rates of students reporting victims of social violence in each age group. It is also found that the rates of students reporting victims of social violence are higher in younger ages (i.e. the lower the age the higher the verbal violence); they are $(23 \%)$ in grades 4 th-6th, $(17 \%)$ in grades 7 th9th and (13\%) in grades 10th-11th. In addition, the proportion of students who report being victims of social violence is higher among students in Arabic-speaking schools (25\%) compared to students in Hebrew-speaking schools (16\%). This gap applies to each age group, but is most pronounced in grades 10th-11th (a gap of $(13 \%$ ) versus $(6 \%)$ in grades 4 th6th and $(9 \%)$ in grades 7 th-9th). Moreover, the gaps between the different age groups in Arabic-speaking schools also appear to be smaller compared to the gaps between the age groups in Hebrew-speaking schools. The gap between the 4th-6th and 10th-11th grades is (5\%) in Arabic-speaking schools and (12\%) in Hebrew-speaking schools.

(5) Violence using digital media: between 2008 and 2017, the stability is evident concerning the rates of students who report violence using both the digital media and social networks in order to harm other students. It was also found that the proportion of students reporting victims of violence using digital media at all stages of age is about (10\%). Studying the statements included in the index, it can be seen that the digital violence directed at students appears to be reflected in distributing abusive messages that occur in the Internet space (7\%) and less in distributing pictures or receiving threats (3\%). In addition, the proportion of students reporting victims of violence using digital media among Arabic speakers (12\%) is higher than the rate reported for Hebrew speakers $(8 \%)$. The gap between the sectors is most pronounced in grades 10th-11th (a gap of $9 \%$ ), while in grades 7 th-9th and grades 4 th-6th there is no actual gap between language sectors. 
In contrast, the proportion of students who report that students use social networks to hurt other students is slightly higher in grades 7th-9th (5\%) compared with grades 10 th-11th and grades 4 th- 6 th $(4 \%$ and $3 \%$, respectively). However, the proportion of students who reported that students use social networks to hurt teachers is slightly higher in grades 10th-11th (4\%) than in grades 7 th-9th (3\%) and grades 4 th-6th (2\%). In addition, the proportion of students who report using students on social networks to harm other students is higher among students in Arabic-speaking schools (5\%) compared to students in Hebrew-speaking schools (3\%). The gap between the sectors is most pronounced in grades 10th-11th (5\%), and is similar in the other two stages of age. Also, the percentage of students reporting that students use social networks to hurt teachers is higher among Arabic-speaking schools (4\%) compared to Hebrew-speaking schools (2\%). This gap is maintained at each of the age stages and stands at $3 \%$ in grades 10 th- 11 th and $2 \%$ in grades 4th-6th and grades 7th-9th.

(6) Sexual Violence: between 2008 and 2017, there was a decrease in the rates of sexual violence victims reported in each age group. It was also found that the percentage of students reporting sexual violence victims in grades 7 th-9th and grades 10th-11th (15\%) was high compared to grades 4 th-6th (10\%). In addition, the proportion of students reporting victims of sexual violence is higher in Arabic-speaking schools (15\%) compared to Hebrew-speaking schools (12\%). The gap between sectors is greater in grades 10th11 th $(6 \%)$ compared to grades 7 th-9th and grades 4 th6th (approximately 1\%).

The School Ways of Dealing with The Phenomena of Violence

For the purpose of coping with violence phenomena, Benvenishti and others (2003) examined the characteristics of interventions that have been shown to be effective in reducing violent behaviors in schools. Their findings suggest that schools must choose an intervention that is appropriate to the schools' unique situation and needs. Successful interventions are those that (RAMA, 2016):

a. Raise the students, teachers, and parents' awareness and sense of responsibility towards the types of violence that are common in their school (whether speaking about sexual harassment, brawls, weapons use, etc.).

b. Create clear guidelines and rules of conduct for the school.

c. Guide all the different social systems in the school, and clarify to the entire school community the procedures that must be followed before, during and after violent acts.

d. Aim at getting the involvement of the school staff, the students and parents in the program.

e. Integrate the program into the school's daily tasks. Based on the aforementioned, the question arises: What are the Arab teachers' attitudes towards school violence?
This question leads to three sub-questions:

i. What are the teachers' attitudes towards the factors that influence the prevalence and intensity of violence within the school?

ii. What are the teachers' attitudes towards the external influencing factors - within the child's family - that influence the prevalence and intensity of school violence?

iii. What are teachers' attitudes towards the ways of addressing school violence beyond using physical exclusion?

\section{Methods}

As mentioned earlier, the importance of this study is based on its research evidence from Arab teachers from Israel, which is relatively little in previous studies. Therefore, this study will have the objectives as detailed below and its uniqueness is not expressed only in terms of the female teachers, who have different seniority years but also of belonging to the Arab sector. Those female teachers teach different subjects in different elementary schools in the north of the country and they have a teaching experience of up to 12 years, (they are 6 female teachers).

\section{The Research Tool}

The study adopted the qualitative approach and conducted in-depth, semi-open interviews with the participants - female teachers. Through the interviews, the researcher clarified the teachers' perception of violence. By analyzing the interviews and comparing the processes and the way teachers act with violent students, the researcher tried to identify the differences and the similarities in the teachers' behavior or actions, and the difference in their competence in dealing with violence.

The interview is dedicated for the teachers, and is composed around the issue of school violence. The interview includes 12 items, and is divided into 2 sections, a demographic section, and a section containing the interview questions. Sample questions from the interview are: "Tell me a little about yourself. Where are you from? What have you been doing before arriving at school?"; "How do you feel about the school atmosphere?"; "What is your opinion concerning school violence cases?"

\section{The Research Procedure and Data Collection Process}

Considering the nature of the subject studied and the underlying goals of the research, I adopted mainly an inductive approach, as the study does not test particular hypotheses, but rather interprets the phenomenon under study and generates theory from the collected data.

The research procedure included the following steps:

a. The researcher gets to the schools in the northern of Israel.

b. The researcher conducts an interview for the 6 participating teachers. 


\section{Ethical Approval of the Research}

The Research Ethics Committee of Sakhnin Academic College for Teachers Education determined that the nature of the research and proposed research process comply with the ethical standards of conducting research. In addition, none of the actions contrary to scientific research and publication ethics were carried out in this study.

\section{Findings}

The findings from the interviews were listed under a number of themes:

Relating to question 1: "What are the teachers' attitudes towards the factors that influence the prevalence and intensity of violence within the school?

The analysis of interviews shows four main categories:

\section{Academic deficiency}

The findings of the study indicate that most of the students who show school violence, were, according to the interviewees, academically weak. At school, they have a meaningful learning deficiency and an achievement gap in comparison with their peers. Most of the interviewees spoke of the low ability of these students to successfully deal with the material being studied, and that the material provided does not adequately address their needs and abilities, and therefore, violent children had difficulty in learning, as the following quotes show:

\section{According to the first interviewee:}

"The students are disturbers; their achievements are low, and some have low self-esteem". The second interviewee adds:

"These students do not know how to listen; they have a problem of attention and concentration; they are boundless, over-irritable; students who need attention; most of their achievements are low and their socioeconomic status is low."

Interviewee 4 adds that violence is the only way for these students to achieve status among their peers:

"They are usually low-scoring students and have lost all other meanings in the school setting. They themselves are students who make troubles during lessons; they have status among other students only because of their use of violence, and usually such students stay in a group for gaining more power."

\section{Alienation and Low Emotional Appreciation}

According to some interviewees, most of the students who acted violently, showed school alienation and low emotional appreciation. Students who demonstrate violence are characterized by a sense of alienation towards the society's values; they show low self-image and self-esteem. Their low educational achievement adds to their low self-image and poor self-esteem and they fail to control themselves. In other words, they have difficulty in their self-control and have no motivation to change the situation. The failure experience haunts the violent children and, at times, brings about their social rejection of their relationships with their classmates and other peers at school, pushing them toward violence. These students are also characterized by their frequent absences from school, and experiencing a feeling of frustration and anger at the material being taught, which is incompatible with their special abilities and needs, as the following quotes demonstrate:

Interviewee 1:

"Typically, we recognize children as physically weak, and children with feelings of inferiority, as well."

Interviewee 2 adds:

"Those students don't know how to listen, and they have an attention-deficit problem; they do not have boundaries, over-irritable and they need attention."

Interviewee 3 adds:

"violent students are students who come from families whose socioeconomic situation is particularly difficult, and they are not highly motivated."

Interviewee 6 adds:

"I think that bullying kids are those who have trouble adjusting and communicating with others; children who are exposed to dangerous behavior in the family; children who undergo or are physically abused within their family or environment."

The Educational Personnel Lack of Intervention Strategies and Methods

Some interviewees stated that educational treatment at school towards the disadvantaged and violent students, is deficient. The school policy sometimes ignore them and their absence from school, without deeply dealing with their problems. According to Interviewee 1:

"Sometimes, on the part of the parents, who do not back up the school, or the teachers' weakness, the surrounding atmosphere becomes hostile."

And when asked her about the ways, which she believes may help addressing school violence, beyond the physical exclusion, interviewee 1 suggests:

"Reducing the number of students in the classroom, supporting parents during crises and training so that they can address their children at home; and making the teacher plays the role of a maternal figure towards the students in these situations, who gives them an open and comfortable feeling, and thus coming to school with motivation."

When we asked interviewee 5 about the factors that influence the prevalence of violence within the school, she responds:

"The prevailing educational climate in the school greatly affects the prevalence of violence as well as the teachers' inability to maintain a safe environment. Moreover, the teachers' failure to identify students suffering from bullying and violence, and their failure to provide care and sharing. In addition, the teachers' failure to provide assistance and support to those victim students of violence. Finally, the inappropriate treatment given to any complaint about bullying results in increasing the violence phenomenon." 
When asking interviewee 5 about the factors that influence the level of violence within the school, she replied:

"Lack of reporting on the violence phenomenon, or the acts that occur within the school; failure to share the relevant parties, who can intervene and assist in eliminating the phenomenon, such as the psychologist, the counselor, and the police - in exceptional cases; and lack of rules within the school. It is very urgent to establish clear and anti-violence rules within the school."

On the other hand, a great part of the interviewees says that the school does not deal with violence effectively, specifically in addressing the academically disadvantaged students and the violent ones. According to interviewee 2 :

"There are no school factors that help intensify any sort of violence."

\section{Attitude towards a Violent Child at School}

The perception of the school should position the student at the center and that the educators must discover his/her strengths by developing a good relationship between them and the student. The teacher-student relationship affects the child's violence, as some teachers mentioned, for example, Interviewer 3 says:

"The atmosphere in the school is very positive; the close relationship between the teachers, the school administration and the students is built on mutual respect."

According to interviewee 4:

"The school acts of violence are relatively small compared to the violence that exists in society. The school has to create a setting that allows a different space with a language of rules, values, and relationships, which based on respect between students and towards their teachers and the principal."

Relating to the second research question: "what are the teachers' attitudes towards the external factors that affect the prevalence and intensity of violence in the school?"

The analysis of interviews shows two categories:

\section{Personal Factors which Lead toward Violence}

According to most interviewees, personal factors have a major and even decisive influence on school violence. Therefore, secure attachment, stable and authoritative parenting, education as a basic value in the family and a stable environment for the child's residence lay the foundations for the development of a child's self-esteem, establish values within the child and develop his/her morals and non-violence. Thus, according to interviewee 5 :

"As stated above, sometimes the bullying students are the ones who have had serious family problems, and the circumstances of their lives do not allow them to live peacefully, and so their internal outrage toward the society comes out as aggressive actions toward others. There are also cases that acting violently depends on the child's personality, i.e., he cannot accept the fact that he is weak, shy or low-achieving."
She adds that the bullying students are those who:

"have low achievements, experience hidden drop-out during class, are aggressive and have a difficult family background. Moreover, those kids may also be powerful students, who want to control the classroom and become dominant la prominent figure in the classroom)."

And according to interviewee 6:

"Students with a weak personality who cannot defend themselves, are students who cannot respond and take steps to help them overcome their distress." Moreover, "disorder, lack of rules and boundaries and people who live in a mess without clear laws, discipline and positive habits, tend to act violently. In addition, lack of order, discipline, boundaries, roles and definitions, turns the impulsive side of humans into more dominant, and the result in violence and a feeling of lack of brace, as if 'everything is allowed."

According to interviewee 8:

"School violence acts can be between students or between students and teachers. I can say that it has to do with the characters of the people. There are polite and calm students, and there are the nervous ones. Teachers usually suffer and try to get along and reach a compromise with the student." She adds that "I can point out that the distressing students are students who cannot concentrate during class without engaging in anything and who always feel the need to provoke someone. Moreover, violent students are those who come from violent families or violent environments and who constantly hear violent sentences. Furthermore, those kids live in a violent family or watch violent movies that could create violent acts and emotions. In short, the family has a big role to play in growing a violent personality in their sons."

\section{Family Factors which Lead toward Violence}

In addition, family factors may also lead the child into violence, including parents' behavior, family difficulties, malfunctioning of family and parents and parents' lack of involvement in the child's life as well as neglecting him/her. These features, which have emerged from the interviewed teachers, influence the children's behavior and push them toward violence, as claimed by interviewee 2 :

"Values that the student receives at home: for example, if the parents themselves are exposed to violence and act aggressively toward the teachers and the principal, they will set an example for their children in such behavior, so the child will act aggressively by imitating his/her parents' acts."

Interviewee 5 adds:

"Students whose family culture is a culture of violence, both indoors, in the neighborhood and wherever they go, are students whose way of life is like that. The thing that prevents them from using violence in the school are the clear, school rules that make such students lessen their use of violence in the school."

Relating to question 3: "what are the teachers' attitudes toward ways of addressing school violence, beyond physical exclusion?" 
In order to address the problem of violence beyond using physically exclusion, we have to study the school climate. Studying the school climate is basically looking at the student's school context, and the interactions that exist between the student and his/her surrounding environment. Therefore, it is important to provide the student with comfortable conditions while being at school. Some interviewees have mentioned the preventive treatment of inclusion, which may reduce the student's level of violence, along with punitive treatment involving the punishment of the violent child. As interviewee 4 states:

"Preventive care is the inclusion of the homeroom teacher, the coordinator, the teachers and the principal while dealing with violent student. As soon as he feels loved and included, $\mathrm{s} / \mathrm{he}$ automatically reduces his/her level of violence. Inclusion is a reason behind less violence at school."

She adds that "punitive treatment is important, especially when using violence. When the punishment is clear and understandable to the student, he internalizes the cost of using violence, and in particular, the teacher's disappointment with it. Many times I saw students being excluded because they use violence, especially, towards their homeroom teacher. The homeroom teacher's response is considered important punishment for preventing another act of violence."

It can be seen that the interviewees note a significant relationship between the teacher and the student. They foster a caring relationship between both sides, and support developing a good and protected feeling for the student, alongside setting boundaries and increasing authority.

To sum up, the findings of the study concerning the teachers' attitudes towards school violence, the ways they react against it and how it was expressed in their work in the Arab sector, were divided into the following themes:

Relating to question 1, "what are the teachers' attitudes towards the factors that influence the prevalence and intensity of violence within the school?

The analysis of interviews conducted with the teachers shows four main categories, which are:

Academic deficiency.

Violent students in the school are academically deficient.

Alienation and low emotional appreciation.

Violent students at school are alienated and emotionally inherited.

Lack of intervention strategies and methods of the school staff.

Violent students at school sometimes suffer from a lack of strategies and intervention methods among the school staff.
Attitude towards a violent child at school.

Violent students at school are sometimes exposed to inappropriate treatment by school staff.

Relating to question 2, "what are the teachers' attitudes towards the external factors affecting the prevalence and level of violence in the school?

Personal factors that lead to violence.

Personal factors have a major impact on student's violence at school.

Family factors that lead to violence.

Family factors may also lead the child into violence, including the parents' behavior, family difficulties, family and parents' malfunctioning, lack of parents' involvement in the child's life and neglecting the child.

Relating to question 3 "what are the teachers' attitudes toward ways of addressing the school violence issue, beyond physical exclusion?

In order to address the problem of violence beyond using physically exclusion, we have to study the school climate. Studying the school climate is basically looking at the student's school context, and the interactions that exist between the student and his/her environment. Therefore, it is important to provide the student with comfortable conditions while being at school.

\section{Discussion and Conclusion}

The current study examines the teachers' attitudes towards school violence issue. It also examines the teachers' attitudes and feelings regarding the phenomenon of violence and also their responses and ways of expressing them.

Choosing to focus on teachers' attitudes and feelings concerning violent behavior patterns is particularly important. It is an aspect that should be taken into account when discussing violence in schools and ways of dealing with it (Idlovitz \& Felishman, 2001).

The main research question: "What are the teachers' attitudes towards school violence?"

This question is divided into three sub-questions as follows: 1. What are the teachers' attitudes towards the factors that influence the prevalence and intensity of violence within the school?

2. What are teachers' attitudes towards the external factors - within the child's family - that influence factors the prevalence and intensity of school violence?

3. What are the teachers' attitudes towards the ways to address school violence beyond using the physical exclusion? 


\section{Discussing the Research Question and the Sub-Questions}

The findings of the interviews could be divided into a number of themes or five major categories, which are:

Relating to question 1: "What are the teachers' attitudes towards the factors that influence the prevalence and intensity of violence within the school?

The findings could be divided into 4 themes, as follows:

Academic deficiency: Violent students in the school suffer from academic deficiency

The findings of the study indicate that most of the students, who act violently at school were, academically weak. They suffer from a learning gap and an achievement gap compared to their peers. Most of the interviewees spoke of the low ability of these students to successfully cope with the material being studied, and that the material provided does not adequately address the needs of the violent children as well as their abilities. Therefore, violent children had difficulty in learning as can be seen from the quotes of the participating teachers. The findings of the research are consistent with the research literature, which states that the more a student experiences failure in studying, the more he will turn to practicing violence (Hess, Horowitz \& Reiter, 2009). Initially, the claim follows the impulse approach - Miller's aggression (Miller, 1958), in which frustration constitutes a behavior-blocking, oriented towards a goal. Blocking creates a negative impulse, leading to violent behavior. And violence is just one of several ways to respond to frustration, yet that not every frustrated person responds aggressively. There are other factors that influence aggression.

\section{Alienation and low emotional appreciation}

Violent students at school feels alienation and poor emotional appreciation. The findings of the study show that most of the students who acts violently showed school alienation and low emotional evaluation. Students who demonstrate violence are characterized by a sense of alienation from the values of the society, a negative self-image and low self-esteem. Their low academic achievement adds to their low self-esteem and poor self-esteem. Moreover, those students fail to control themselves, that is, they have difficulty in their self-control, rejection of satisfaction, as well as demotivation to change.

The 'failure' experience chases the violent children and at times, brings about their social rejection with their relationships with their classmates and other peers at school. It also pushes them toward violence. These students are also characterized by frequent absences from school, and a feeling of frustration and anger at the material being taught, which is incompatible with their special abilities and needs. These findings are also consistent with the research literature - the claim of Hess, Horowitz and Reiter (2009) which is based on the impulse-aggression approach. According to this approach, the more the student feels detached from what is being done at school, the more he will resort to act violently (Hess, Horowitz \& Reiter, 2009; Shihadi, 2015).

\section{Lack of intervention strategies and methods of the school staff}

The findings indicate that violent students at school sometimes suffer from a lack of strategies and intervention methods from the school staff. This is also consistent with the existing research, and with the argument that school climate plays a very important role in reducing violence. A positive climate in the school maintains a consistent and clear policy against the phenomena of school violence, and promotes the relationships on the part of the school staff that support the students, encourage them to participate in school decision-making processes when setting violence prevention programs. All these steps and others can decrease levels of school violence.

RAMA's report (2016) which examined the student's sense of protection in the school, includes:

- Feeling confident and protected at school.

- Not fearing threatening and harassment practiced by other students at school.

- Not fearing injury and physical violence practiced by other students at school.

RAMA's report (2016) found that the percentage of students who report feeling protected at school is high, i.e., $85 \%$ in grades 10,11 and $12,80 \%$ in grades 4,5 , and 6 and $81 \%$ in classes 7, 8 and 9 .

However, when examining the school efforts for preventing school violence, these aspects were examined:

- The success of the teachers to deal with "troublemakers".

- In case of complaining from any student, the teachers stand with the complainant.

- The school has clear rules against violence.

- A general feeling that school is making great efforts to prevent violence from happening.

According to the students' reports, RAMA's report (2016) found that the older the age, the lower the school's efforts in preventing violence. For example, if $81 \%$ of 4 th till 6 th graders reported that the school makes efforts to prevent violence, then it would drop to $67 \%$ among 7 th till gth graders and $64 \%$ among 10 th till 11 th graders.

\section{Attitude towards a violent child at school}

Violent students at school are sometimes exposed to inappropriate treatment by school staff. Some interviewees stated that the educational treatment at school does not always support the violent students nor the disabled ones and the school policy sometimes simply ignores them and their absence from school, without deeply studying their problem. School should position the student at the center of its concerns, and teachers should reveal the students' strengths by developing a good relationship between them and their students. The teacher-student relationship affects the child's 
violent acts, as some teachers have mentioned. This very finding is consistent with previous research, and with the way in which the impulse approach deals with violence. This approach sees violent behavior as a response to frustration, and therefore it is urgent to deal with the phenomena of violence by reducing the opportunities for the student to experience frustration. As the number of environmental and intrapersonal events that causes frustration diminishes, so does the violence.

This approach, which sees violence as a response to a frustrating experience, seeks to exclude and reduce as much as possible the amount of frustration that the person encounters. The strategy of this approach has a typical trend - the permissive. According to this trend, it is best to create a life frame for a person without bans, that are fixed by external factors which he has no control over. It is better for the person to decide for himself what is allowed and what is forbidden, after studying any matter and considering it independently. This way, the person will translate the frustrating experience into an explained event, which, by understanding it, may facilitate its acceptance without experiencing frustration.

Relating to question 2: "What are the teachers' attitudes towards the external factors that affect the prevalence and intensity of violence in the school?"

\section{Personal factors, which lead toward violence}

According to most interviewees, personal factors, such as personality, have a major impact on school violence.

The study reveals that family factors may also lead the child to violence, including: parents' behavior, family difficulties, family and parents' dysfunction, parents' neglect and parents' noninvolvement in the child's life. All of these characteristics, which emerged from all interviewed teachers, influence the child's behavior and push him toward acting violently. This finding is in consistent with the existing research, which asserts that parenting style influences the likelihood that kids will behave violently. Lack of direct involvement in the child's life and lack of warmth on the part of his parents increase the likelihood of violent behavior on the part of the child (RAMA, 2016; Reuveni, 2011).

However, even parenting style that has no clear boundaries against violent behaviors, or that permits violent behavior, increases the likelihood that the child will behave violently. The parent is himself a role model for violent behavior, increasing the likelihood that the child will internalize this model and become violent himself (RAMA, 2016; Reuveni, 2011).

Moreover, in relation to the family of the child, the interviewee's comments are in consistent with RAMA's (2016) report, which reveals that the community in which the school operates and the family's ethnic and economic background of the student affect the violence within the school. Therefore, the school and its students operate within a particular social context. This social context is the community, which, if characterized by poverty and high crime rates, and a paucity of opportunities to acquire education and find suitable employment, will increase the likelihood of violence occurring in the schools.
In many cases, the students' ethnicity or family culture is closely linked to educational-socio-economic status, and therefore the level of school violence stems from the differences in the educational-socio-economic aspects which are related to the ethnic and cultural differences that affect it. According to Reuveni (2011), there is a connection between the prevalence of violence and the socio-economic level of the student. Schools whose populations belong to a moderate socioeconomic status, the prevalence of violence - both physical and property - was higher compared to schools whose populations belong to a high socioeconomic status. Relating to question 3: "What are the teachers' attitudes toward ways of addressing school violence, beyond using physical exclusion?"

The interviewees did not present many ways of addressing school violence. Only some of the interviewees responded and talked about a type of preventive treatment of inclusion, which may reduce the student's level of violence, along with punitive treatment, which involves imposing a punishment on the violent child.

This finding is partially consistent with the research literature and with the findings of RAMA (2016) and with the claim that the school climate plays a very important role in reducing violence. A positive climate in the school maintains a consistent and clear policy against school violence and promotes relationships on the side of the educational staff, that encourage students' participation in school decision-making process in regard to violence prevention programs. All these steps reduce the levels of school violence.

According to RAMA's report (2016), the most obvious way students suggested for dealing with violence was setting clear anti-violence rules at school; the percentage of the students who reported an increase in violence reached $81 \%$.

\section{Limitations of the Study}

In general, although this study has yielded important results, they may be partial and incomplete for a number of reasons: The participant teachers faced a difficulty of knowing and understanding the children's situation due to insufficient knowledge and familiarity of the children and their family background, the concerns of the teachers to get involved in the child's family, and the consequences that this intervention may have, which may turn it difficult to collect information and so it limited the data.

Another limitation of the study is that the researchers did not spend enough time in the research site, which leads to lose a lot of children's behaviors, and to comprehensively recognize the school and its staff as well as getting in a close contact with the students. This would have provided the researchers with a richer perspective on the subject.

If the observation was used as a tool, that may also have been beneficial for reaching a deeper recognition of the population being studied and for constructing and imparting meaning for the teachers' views.

The current research is also limited to the possibility of generalizing its findings because in qualitative research it is possible to generalize only with reference to the categories that 
characterize the research (Shkedi, 2003); still the reader is limited in his possibility to generalize only to those categories.

Moreover, the study is limited to generalization due to having only female-teacher participants and women who belong only to the Arab sector. The results of the research may have changed, if the study participants were men or from a different sector.

Finally, the study does not seek to recommend behaviors in the field, but rather try to understand the totality of attitudes of the teachers investigated.

\section{Suggestions for Further Research}

In a follow-up study, one can examine whether there is a relationship not only between the teachers' attitudes towards violence and the good performance of teachers in the process of preventing violence but also the relationship between the students' attitudes towards violence and the good performance of teachers in the process of preventing violence.

It will be interesting to examine how the parents of students perceive the violent acts of their children at school, and whether there are differences in the perceptions of parents and teachers towards the phenomena of student violence. Finally, future research could examine the attitudes of teachers who belong to other populations, such as Jewish sector teachers or ultra-Orthodox education, and compare their attitudes.

\section{Publishing Ethics Statement}

The Research Ethics Committee of Sakhnin Academic College for Teachers Education determined that the nature of the research and proposed research process comply with the ethical standards of conducting research. In addition, none of the actions contrary to scientific research and publication ethics were carried out in this study.

\section{References}

Abu Asaba, H., Karakra-Ibrahim A. \& Abu Katsh, A. (2018). Proposing an intervention program with teachers at schools to prevent violence. Jamaah, 21(1), 154-145.

Addington, L. A. (2009). Studying the crime problem with NIBRS data: Current uses and future trends. In M. Krohn, A. Lizotte, \& G. Hall (Eds.), Handbook on crime and deviance (pp. 23-58). New York, NY: Springer

Álvarez, L., Álvarez-Garcia, D., González-Castro, P., Núñez, J.C. \& González-Pienda, J. A. (2006). Evaluación de los comportamientos violentos en los centros educativos. Psicothema, 18, 686-695

Álvarez-García, D., Barreiro-Collazo, A., Núñez, J. C. \& Dobarro, A. (2016). Validity and reliability of the Cyber-Aggression Questionnaire for Adolescents (CYBA). The European Journal of Psychology Applied to Legal Context, 8(2), 69-77.
Álvarez-Garcia, D., Rodríguez, C., González-Castro, P., Núñez, J. C. \& Álvarez, L. (2010). La formación de los futuros docentes frente a la violencia escolar. Revista de Psicodidáctica, 15(1), 35-56.

Amit, H. (2012). Educational leadership for prevention of violence. Modan.

Bandura, A. (1983). Psychological mechanisms of aggression. In R. G. Geen \& E. Donnerstein (Eds.), Aggression: Theoretical and empirical reviews (pp. 1-40). New York: Academic Press.

Barrett, K., Lynch, M. \& Stretesky, P. (2016). Green Criminology and the reconceptualization of school violence: Comparing green school violence and traditional forms of school violence for school children. Critical Criminology, 24(1), 19-37.

Benvenishti, R., Khursi-Ksabari, M. \& Astor, R. (2005). Violence in the educational system. School of Social Work: Hebrew University of Jerusalem.

Berkovitz, R., Tsafrir, S. \& Anush, J. (2017). Exposed in turret: Violence towards school teachers. Organizational Research and Human Resource Management Quarterly 2(1), 7-30

Berkowitz, R., Glickman, H., Benbenishty, R., Ben-Artzi, E., Raz, T., Lipshtadt, N., \& Astor, R. A. (2015). Compensating, mediating, and moderating effects of school climate on academic achievement gaps in Israel. Teachers College Record, 117, 1-34.

Calvete, E., Orue, I., Estévez, A., Villardón, L., \& Padilla, P. (2010). Cyberbullying in adolescents: Modalities and aggressors' profile. Computers in Human Behavior, 26(5), 1128-1135.

Cornell, D., Shukla, K., \& Konold, T. (2015). Peer victimization and authoritative school climate: A multilevel approach. Journal of Educational Psychology. http://dx. doi.org/10.1037/edu0000038

Danner, M. \& Carmody, D. (2001). Missing gender in cases of infamous school violence: Investigating research and media explanations. Justice Quarterly, 18(1), 87-114.

Defensor del Pueblo-UNICEF (2007). Violencia Escolar: El Maltrato entre Iguales en la Educación Secundaria Obligatoria 1999-2006. Nuevo estudio y actualización del Informe 2000 Elaborado por C. del Barrio, MA. Espinosa, E. Martín, E. Ochaíta, I. Montero, A. Barrios, MJ. de Dios y H. Gutiérrez. Madrid: Publicaciones de la Oficina del Defensor del Pueblo.

Elliott, D. S., Hamburg, B., \& Williams, K. R. (1998). Violence in American schools: An overview. In D. S. Elliott, H. Hamburg, \& K. R. Williams (Eds.). Violence in American schools: A new perspective (pp.3-28). New York, NY: Cambridge University Press.

Estévez, E., \& Jiménez, T. I. (2015). Conducta agresiva y ajuste personal y escolar en una muestra de estudiantes adolescentes espanoles. Universitas Psychologica, 14, 111-124. 
Félix-Mateo, V., Soriano-Ferrer, M., Godoy-Mesas, C. \& Sancho-Vicente, S. (2010). El ciberacoso en la enseñanza obligatoria. Aula Abierta, 38, 47-58.

Herrera, M., Romera, E., Ortega, R. \& Gómez, O. (2016). Influence of social motivation, self-perception of social efficacy and normative adjustment in the peer setting. Psicothema, 28(1), 32-39.

Hess, A., Horowitz, T. \& Reiter, S. A. (2009). Social learning linked to violence among Bedouin youth: A meeting for educational-social work. Gilion, 29, 142-129.

Horvetz, T. \& Frenkel, H. (1990). Understanding teenager's violence trends. Jerusalem: Szold Institute.

Lacey, A. \& Cornell, D. (2013). The Impact of Teasing and Bullying on School wide Academic Performance. Journal of Applied School Psychology, 29, 262-283.

Margalit, M. (1998). Mentally retarded children's loneliness: individual and systematic characteristics and treatment approaches. In: A.Duvdevani et al. (Eds.) Parenting and developmental disability in Israel. Jerusalem: Magnes.

Moral, G. Suárez,, C. Villarreal, M. \& Musitu, G. (2014). Tipos de víctimas agresivas en situaciones de bullying en Educación Secundaria. Infancia y Aprendizaje, 37(2): 399-428.

Moral, G., Suárez, C., \& Musitu, G. (2012). Peer roles and bullyig at school: A qualitative study. Revista de Psicología y Educación, 7, 105-127.

Noymeir, M. (1992). Psychology meetings. Third meeting on social psychology. Even Yehuda: Rehess.

Pachter, L. M., Bernstein, B. A., Szalacha, L. A., \& Coll, C. G. (2010). Perceived racism and discrimination in children and youths: An exploratory study. Health \& Social Work, 35(1), 61-70.

Peets, K., \& Kikas, E. (2006). Aggressive strategies and victimization during adolescence: Grade and gender differences, and cross-informant agreement. Aggressive Behavior, 32(1), 68-79.

Pérez-Carbonell, A., Ramos-Santana, G. \& Serrano, M. (2016). Formación del profesorado de educación secundaria obligatoria para la prevención e intervención en acoso escolar. Algunos indicadores. Educar, 52(1), 51-70.

Peterson, R. \& Skiba, R. (2001). Creating school climates that prevent school violence. Preventing School Failure: Alternative Education for Children and Youth, 44, 122-129.

RAMA (The National Authority for Measurement and Evaluation in Education). (2011). Monitoring the level of violence in schools according to student reports. Retrieved from: http://cms.education.gov. $\mathrm{il} / \mathrm{NR} /$ rdonlyres/9DEB836A-7B74-4BCF-A21C5921D5D2784D/170808/Nitur_Alimut_Report_f1.pdf
RAMA (The National Authority for Measurement and Evaluation in Education). (2016). Monitoring the level of violence in schools according to student reports. Retrieved from: http://edu.govil/owlHeb/Yesodi/RegulationsAndAdministrations/Safety/Documents/Nitur_Alimut_Report_2015.pdf

RAMA (The National Authority for Measurement and Evaluation in Education). (2018). Monitoring the level of violence in schools according to student reports. Retrieved from: http://meyda.education.gov.il/files/ Rama/Nitur_Alimut_Report_Students_2017.pdf

Reubeny, T. (2011). Violence among elementary school students - prevalence, influence and ways of coping with victims of violence. In Hannah Ezer, Isaac Gilat \& Sagi Rachel (Eds.). I feel completely alone in this story. The coping of Israeli young people in stress and distress situations - A file of research in education and society. Mofet Institute Publishing.

Shihadi, N. (2015). Pedagogical and psychological approaches of violence in school. Studia Universitatis Moldaviae: Stiinte ale Educatiei, 5(85), 112-118.

Tzafar Ben-Yoshua, N. (1999). The qualitative research in teaching and learning. Givatayim: Modan.

Yosiphon, M. (2001). Case study. In N. Ben-Yoshua Tzafar (Ed.). Traditions and streams in qualitative research. Lod: Mofet Institute - Dvir. 